\title{
PERMINTAAN KONSUMEN TERHADAP SAYURAN ORGANIK DI PASAR PULAU SAPARUA
}

\author{
Natelda R. Timisela ${ }^{1}$, Marfin Lawalata ${ }^{1}$, Valenszya Jozias ${ }^{1}$, Febby J. Polnaya ${ }^{2}$, Stevianus \\ Titaley $^{3}$
}

\author{
${ }^{1}$ Jurusan Sosial Ekonomi Pertanian Fakultas Pertanian Universitas Pattimura \\ ${ }^{2} J u r u s a n$ Teknologi Hasil Pertanian Fakultas Pertanian Universitas Pattimura \\ ${ }^{3}$ Jurusan Teknik Mesin Fakultas Teknik Universitas Pattimura \\ Jl. Ir. M. Putuhena, Poka, Teluk Ambon, Ambon 97233 \\ *Corresponding author: natelda.timisela@faperta.unpatti.ac.id
}

\begin{abstract}
The purpose of the study was to analyze consumer demand for organic vegetables in Saparua Island, Central Maluku Regency. Organic vegetables are environmentally friendly and more to the concept of nature (back to nature). The research sampling technique was done by accidental sampling. The number of research sample was 40 people. Based on the ANOVA test results obtained F-count 17.630> F-table 2.64 means that the price of organic vegetables, the price of nonorganic vegetables, income, and family members simultaneously have a significant influence on consumer demand for organic vegetables in Saparua Island. However, partial testing shows that the variables that significantly effect on demand for organic vegetables are the price of organic vegetables, the price of non-organic vegetables, the number of family members, the taste and frequency of purchase.
\end{abstract}

Keywords: demand, organic, vegetables, consumer

\begin{abstract}
Abstrak: Penelitian ini bertujuan untuk menganalisis permintaan konsumen terhadap sayuran organik di Pulau Saparua Kabupaten Maluku Tengah. Sayuran organik bersifat ramah lingkungan dan lebih pada konsep alam (back to nature). Teknik pengambilan sampel penelitian dilakukan dengan accidental sampling. Jumlah sampel penelitian sebanyak 40 orang. Analisis data penelitian secara kuantitatif menggunakan regresi berganda. Hasil analisis diperoleh F-hitung 17,630> F-tabel 2,64 artinya harga sayuran organik, harga sayuran non-organik, pendapatan dan anggota keluarga secara simultan berpengaruh signifikan terhadap permintaan konsumen terhadap sayuran organik di Pulau Saparua. Hasil analisis secara parsial menunjukkan bahwa variabel yang berpengaruh signifikan terhadap permintaan sayuran organik adalah variabel harga sayuran organik, harga sayuran non organik, jumlah anggota keluarga, selera dan frekuensi pembelian.
\end{abstract}

Kata kunci: permintaan, sayuran, organik, konsumen

\section{PENDAHULUAN}

Masyarakat di negara maju maupun negara berkembang memusatkan perhatian pada sektor pertanian seiring terjadinya pola hidup masyarakat yang telah mengalami perubahan yakni lebih mementingkan kualitas kesehatan, baik kesehatan manusia maupun lingkungan terkait dengan pertanian organik (Hubeis et al., 2013). Saat ini pertanian organik diminati oleh banyak negara di dunia. Hal ini karena pengelolaan pertanian organik mengutamakan prinsip kesehatan, keadilan, ekologi dan perlidungan. Pertanian organik menjunjung prinsip kesehatan dengan memperhatikan kelestarian dan peningkatan kesehatan tanah, hewan, tanaman dan manusia yang merupakan komponen yang tidak terpisahkan dan berhubungan (Mayrowani, 2012). 
Pertanian organik bertujuan untuk mengoptimalkan kesehatan dan produktivitas mikroorganisme tanah, hewan, tumbuhan dan manusia. Dalam perkembangannya pertanian organik bermanfaat bagi masyarakat dan tidak dipisahkan dari dimensi ekonomi, lingkungan dan sosial. Pertanian organik menjadi menarik karena perhatian orang akan terbentuk yakni muncul kesadaran akan bahaya akibat penggunaan bahan kimia berlebihan. Oleh sebab itu konsumen terdorong untuk memilih bahan pangan yang aman untuk dikonsumsi karena aman untuk kesehatan sehingga permintaan produk organik akan semakin meningkat.

Budidaya sayuran organik saat ini banyak berkembang di daerah perkotaan dan pedesaan. Hal ini disebabkan sayuran organik ramah lingkungan dan dikenal dengan konsep kembali ke alam (back to nature). Sayuran organik yang dibudidayakan seutuhnya tanpa pupuk dan pestisida kimia. Sayuran organik harus bebas residu kimia supaya layak dimakan sehingga tubuh menjadi sehat. Isdiayanti (2007) menjelaskan bahwa sayuran organik diminati dan dikembangkan saat ini karena budidaya sayuran organik tidak memakai pupuk dan pestisida kimia. Rahman, et al. (2015) mengemukakan bahwa sayuran organik memiliki 50\% lebih banyak antioksidan dari sayuran anorganik, dapat menurunkan resiko penyakit kanker dan jantung.

Sayuran organik mengandung antioksidan $10-15 \%$ lebih tinggi dari sayuran anorganik, ini merupakan keistimewaan sayuran organik. Antioksidan dibutuhkan oleh tubuh karena mampu menyembuhkan penyakit dan zat kekebalan tubuh. Kandungan dalam sayuran dan buah organik seperti vitamin $\mathrm{C}$ dan mineral esensial yaitu fosfor, magnesium, zat besi dan krom, kalium semuanya lebih tinggi dari sayuran dan buahan anorganik.

Perkembangan sayuran organik di Propinsi Maluku dimulai tahun 2010. Petani Dusun Telaga kodok Kabupaten Maluku Tengah tahun 2010 memulai berusaha sayuran organik. Kelompok petani di Dusun Telaga Kodok awalnya memanfaatkan lahan pekarangan dan lahan kebun milik sendiri. Lahan pekarangan dan lahan kebun berdekatan dengan pemukiman warga sehingga memudahkan petani untuk mengontrol proses produksi sayuran organik, (Timisela, 2017)
(Timisela et al., 2017). Tahun 2014 usahatani sayuran organik mulai berkembang di Dusun Aerlow dan Desa Waai, (Timisela et al., 2018). Sayuran hasil pertanian organik memiliki kualitas tinggi, sebab proses penanaman sayuran menggunakan sistem multikultur dan memiliki biodiversitas tinggi sehingga sayuran hasil pertanian organik akan memiliki kandungan polusi yang diabaikan dan kandungan nutrisi yang tinggi (Winangun, 2005). Petani Dusun Telaga Kodok, Dusun Aerlow dan Desa Waaisalama ini sebagai pemasok sayuran organic di Kota Ambon.

Semua hasil panen sayuran organik dipasarkan di pasar modern Fris Market dan Supermarket Dian Pertiwi Ambon. Tahun 2018 perkembangan budidaya sayuran organik sudah menjalar sampai ke luar Kota Ambon. Salah satu pulau di Propinsi Maluku yang petaninya mulai membudidayakan sayuran organik adalah Pulau Saparua. Hasil panen sayuran organik langsung di jual ke pasar utama Saparua Kota. Konsumen sebagai pengguna akhir mulai melirik sayuran organik karena mendengar informasi bahwa sayuran organik baik untuk kesehatan dan meningkatkan keamanan lingkungan. Oleh sebab itu konsumen tertarik untuk membeli dan mengkonsumsi sayuran organik secara kontinu. Berdasarkan uraian di atas maka tujuan penelitian adalah menganalisis permintaan konsumen terhadap sayuran organik di Pasar Saparua Kabupaten Maluku Tengah.

\section{METODE PENELITIAN}

Penelitian dilaksanakan di Pasar Pulau Saparua, Kabupaten Maluku Tengah. Pemilihan lokasi secara sengaja karena pasar Pulau Saparua merupakan pasar yang telah menyediakan sayuran organik. Metode penelitian ini yakni survey merupakan kegiatan penyelidikan atau pengamatan yang kritis terhadap keterangan dari suatu persoalan tertentu. Selain itu metode survey juga menggunakan kuesioner sebagai instrument pengumpulan data (Kriyantono, 2006). Teknik pengambilan sampel dilakukan secara insidental yaitu sampel diambil secara kebetulan. Sugiyono (2018) mengatakan bahwa sampling insidental adalah penentuan sampel berdasarkan kebetulan, yakni peneliti secara kebetulan bertemu dengan konsumen secara 
langsung dan dianggap cocok sebagai informan kunci. Sampel konsumen berjumlah 40 orang.

Data penelitian dianalisis secara kuantitatif yaitu menggunakan model regresi berganda. Faktor-faktor yang memengaruhi permintaan konsumen seperti harga sayuran organic, harga sayuran non organic, pendapatan konsumen, jumlah anggota keluarga, selera dan frekuensi pembelian. Selera dan frekuensi pembelian merupakan variable kualitatif diukur dengan menggunakan skala likert. Skala likert untuk variable selera antara lain sangat suka, suka dan tidak suka sedangkan variable frekuensi pembelian antara lain sering, kadangkadang dan jarang. Persamaan fungsi faktorfaktor yang memengaruhi permintaan sayuran organic sebagai berikut.

$$
\begin{aligned}
\mathrm{Y}= & \mathrm{b}_{0}+\mathrm{b}_{1} \mathrm{X}_{1}+\mathrm{b}_{2} \mathrm{X}_{2}+\mathrm{b}_{3} \mathrm{X}_{3}+\mathrm{b}_{4} \mathrm{X}_{4}+\mathrm{b}_{5} \mathrm{X}_{5}+ \\
& \mathrm{b}_{6} \mathrm{X}_{6}+\mathrm{e}
\end{aligned}
$$

Keterangan:

$\mathrm{Y}=$ Permintaan sayuran organik $(\mathrm{Kg} /$ Bulan$)$

$\mathrm{X}_{1} \quad=$ Harga sayuran organik $(\mathrm{Rp} / \mathrm{Kg})$

$\mathrm{X}_{2}=$ Harga sayuran non organik $(\mathrm{Rp} / \mathrm{Kg})$

$\mathrm{X}_{3}=$ Pendapatan konsumen (Rp/Bulan)

$\mathrm{X}_{4}=$ Jumlah Anggota Keluarga

$\mathrm{X}_{5}=$ selera

$\mathrm{X}_{6}=$ frekuensi pembelian

$\mathrm{b}_{0}=$ Intercept

$\mathrm{e} \quad=$ error (galat)

Menganalisis hubungan karakteristik sosial ekonomi terhadap keputusan pembelian sayuran organik menggunakan analisis korelasi pearson. Keputusan pembelian adalah kegiatan individu yang secara langsung terlibat dalam pengambilan keputusan untuk melakukan pembelian terhap produk yang ditawarkan oleh penjual. Indikator keputusan pembelian yang diukur yaitu kemantapan membeli dan melakukan pembelian ulang.

\section{HASIL DAN PEMBAHASAN}

\section{Karakteristik Responden}

Responden penelitian adalah konsumen yang bertemu dengan peneliti di pasar secara kebetulan kemudian diminta kesediaan untuk diwawancarai guna memperoleh data terkait karakteristik responden dan informasi tentang permintaan sayuran organik di pasar Pulau Saparua.

Tabel 1 menampilkan karakteristik responden meliputi tingkatan pendidikan, umur, jumlah anggota keluarga dan tingkat pendapatan konsumen. Tabel 1 menunjukkan bahwa umur responden bervariasi dan termasuk umur produktif. Terlihat bahwa konsumen dengan kategori umur 31-50 tahun cenderung lebih banyak dijumpai di pasar yaitu sebesar $67,5 \%$, sedangkan konsumen berumur 21-30 tahun dan konsumen berumur 51-60 tahun lebih sedikit dijumpai di pasar yaitu sebesar 32,5\%. Hal ini berarti bahwa kepedulian untuk mengkosumsi sayuran organik tinggi karena berkaitan dengan kondisi kesehatan yang harus terus dijaga pada kondisi umur tersebut. Konsumen ke pasar dalam seminggu dua kali berarti frekuensi konsumsi sayuran organik dalam seminggu dua kali.

Tabel 1 terlihat bahwa responden pada kategori pendidikan SLTA dan Sarjana cenderung lebih banyak dijumpai di pasar pada saat membeli sayuran organik yaitu sebesar 72.5\%. Konsumen berpendidikan SLTA dan Sarjana lebih mengetahui manfaat mengkonsumsi sayuran organik bagi kesehatan karena banyak membaca dan mengadopsi informasi terkait bahan pangan organik. Tingkat kesadaran untuk mengkonsumsi bahan pangan organik lebih tinggi sehingga ketika ke pasar mereka cenderung mencari sayuran organik sebagai bahan pangan aman untuk dikonsumsi. Hasil ini sesuai dengan pendapat Lockie et al. (2002), bahwa konsumen dengan pendidikan tinggi lebih cenderung membeli produk organik.

Jumlah anggota keluarga konsumen menunjukkan bahwa berapa banyak orang dalam keluarga yang mengkosumsi sayuran organik. Telihat pada tabel 1 bahwa jumlah anggota keluarga 2-3 orang sebanyak 40\% cenderung membelajankan uangnya untuk sayuran organik guna dikonsumsi oleh keluarga. Hal ini didukung oleh penelitian Deliana (2012), bahwa anggota keluarga kecil ( $<3$ orang) lebih menyukai sayuran organik, dengan frekuensi pembelian 3-5 kali dalam sebulan, karena kelompok ini telah mapan secara ekonomi dan berpendidikan. Rumah tangga dengan ukuran 
Timisela, N. R., Lawalata, M., Jozias, V., Polnaya, F. J., Titaley, S.: Permintaan Konsumen ...

Tabel 1. Karakteristik respoden meliputi umur, tingkat pendidikan, jumlah anggota keluarga dan tingkat pendapatan

\begin{tabular}{|c|c|c|}
\hline \multirow{2}{*}{ Uraian } & \multicolumn{2}{|c|}{ Konsumen } \\
\hline & Jumlah (orang) & Persentase (\%) \\
\hline \multicolumn{3}{|l|}{ Umur } \\
\hline $21-30$ & 5 & 12,5 \\
\hline $31-40$ & 15 & 37,5 \\
\hline $41-50$ & 12 & 30 \\
\hline $51-60$ & 8 & 20 \\
\hline Total & 40 & 100 \\
\hline \multicolumn{3}{|l|}{ Pendidikan } \\
\hline SD & 4 & 10 \\
\hline SLTP & 6 & 15 \\
\hline SLTA & 14 & 35 \\
\hline D3 & 1 & 2,5 \\
\hline Sarjana & 15 & 37,5 \\
\hline Total & 40 & 100 \\
\hline \multicolumn{3}{|c|}{ Jumlah Anggota Keluarga (Orang) } \\
\hline$<2$ & 10 & 25 \\
\hline $2-3$ & 16 & 40 \\
\hline $3-5$ & 9 & 22,5 \\
\hline$>5$ & 5 & 12,5 \\
\hline Total & 40 & 100 \\
\hline \multicolumn{3}{|l|}{ Tingkat Pendapatan (Rp.) } \\
\hline$<500.000$ & 9 & 22,5 \\
\hline $600.000-1.000 .000$ & 10 & 25 \\
\hline $1.100 .000-2.000 .000$ & 8 & 20 \\
\hline 2.100.000-3.000.000 & 10 & 25 \\
\hline$>3.000 .000$ & 3 & 7,5 \\
\hline Total & 40 & 100 \\
\hline
\end{tabular}

Sumber: Data Primer, 2020; Jozias et al., 2020

keluarga yang lebih kecil ditemukan lebih sadar akan makanan organik dan menunjukkan sikap kesediaan untuk membayar pembelian makanan organik (Soler et al., 2002).

Tingkat pendapatan menjadi pertimbangan seseorang untuk membelanjakan uangnya guna mendapatkan barang dan jasa. Konsumen yang berpendapatan menengah ke atas akan memilih barang-barang yang baik. Namun di daerah pedesaan, pendapatan seseorang bukan jaminan bahwa konsumen akan memiliki barang bagus dan bermerek (Jozias et al., 2020). Tinggi rendahnya pendapatan responden terkait dengan kemampuan responden untuk membeli sayuran organik. Tabel 1 menunjukkan bahwa tingkat pendapatan konsumen bervariasi mulai dari lebih kecil Rp500.000 sampai lebih besar Rp3.000.000. Responden berpendapatan Rp600.000-1.000.000 dan 2.100.0003.000.000 sebanyak 50\%. Tingkat pendapatan tersebut tergolong cukup baik untuk konsumen membeli sayuran organic. Konsumen berpendapat bahwa tinggi atau rendahnya tingkat pendapatan, mereka terus mengkonsumsi sayuran organik karena bermanfaat bagi kesehatan tubuh.

\section{Hubungan Karakteristik Responden dengan Keputusan Membeli Sayuran Organik}

Karakteristik responden yang berpengaruh dalam keputusan untuk membeli sayuran organik antara lain umur, pendidikan, jumlah anggota keluarga dan tingkat pendapatan. Hasil analisis ditampilkan pada Tabel 2. Keputusan dan kesadaran pembelian makanan organik dipengaruhi oleh profil sosio-demografi, perilaku pembelian makanan dan pengetahuan gizi konsumen (Briz dan Ward, 2009; Gracia dan Magistris, 2002; Lockie et al., 2002; Tsakiridou et al., 2006). Keputusan pembelian ini dikaji berdasarkan dua indikator yaitu 
Timisela, N. R., Lawalata, M., Jozias, V., Polnaya, F. J., Titaley, S.: Permintaan Konsumen ...

kemantapan membeli dan melakukan pembelian ulang. Tabel 2 menunjukkan bahwa jumlah responden yang memiliki kemantapan membeli sayuran organic sebanyak 25 orang dan konsumen yang melakukan pembelian ulang sebanyak 15 orang untuk semua kategori yaitu umur, pendidikan, jumlah anggota keluarga dan tingkat pendapatan.

Tabel 2 menunjukkan bahwa umur tidak memengaruhi konsumen dalam pengambilan keputusan untuk pembelian sayuran organik. Umur merupakan kemampuan berpikir dan cara pandang seseorang dalam penentuan sikap dan tindakan guna memiliki sesuatu. Sayuran organik yang kaya vitamin, mineral, kalori dan lainnya yang dikonsumsi oleh semua tingkatan umur. Jika responden ada yang membeli sayuran organik sesuai kebutuhan berarti tergantung kategori umur berapa responden mengkonsumsi sayuran organik. Nilai $p$-value $0,812>0,25$ hal artinya tidak terdapat hubungan erat antara umur dengan keputusan pembelian sayuran organik oleh konsumen. Responden selalu berpikir bahwa umur berapapun mereka tetap harus mengkonsumsi sayuran organik karena untuk menjaga kesehatan tubuh dan sangat baik untuk lingkungan yang sehat.

Tingkat pendidikan berpengaruh terhadap keputusan konsumen untuk pembelian sayuran organik. Nilai p-value 0,042 $<0,25$ artinya terdapat hubungan erat antara tingkat pendidikan dengan keputusan pembelian membeli sayuran organik. Tingkatan pendidikan menggambarkan persepsi seorang konsumen dalam mengkonsumsi sayuran organik. Konsumen mempunyai pemikiran yang luas dan terbuka akan manfaat makan sayuran organik bagi kesehatan dirinya dan keluarganya. Pendidikan sebagai faktor yang

Tabel 2. Analisis karakteristik responden dengan keputusan membeli sayuran organik

\begin{tabular}{|c|c|c|c|c|c|}
\hline \multirow{3}{*}{ Uraian } & \multicolumn{4}{|c|}{ Keputusan Membeli Sayuran Organik } & \multirow{3}{*}{$\begin{array}{c}P- \\
\text { Value }\end{array}$} \\
\hline & \multicolumn{2}{|c|}{ Kemantapan Membeli } & \multicolumn{2}{|c|}{ Melakukan Pembelian Ulang } & \\
\hline & Jumlah (orang) & Persentase (\%) & Jumlah (orang) & Persentase (\%) & \\
\hline \multicolumn{6}{|l|}{ Umur } \\
\hline $21-30$ & 2 & 8 & 3 & 20 & \multirow{4}{*}{0,812} \\
\hline $31-40$ & 10 & 40 & 5 & 33,33 & \\
\hline $41-50$ & 8 & 32 & 4 & 26,67 & \\
\hline $51-60$ & 5 & 20 & 3 & 20 & \\
\hline Total & 25 & 100 & 15 & 100 & \\
\hline \multicolumn{6}{|l|}{ Pendidikan } \\
\hline SD & 2 & 8,00 & 2 & 13,33 & \multirow{5}{*}{0,042} \\
\hline SLTP & 4 & 16,00 & 2 & 13,33 & \\
\hline SLTA & 8 & 32,00 & 6 & 40,00 & \\
\hline D3 & 1 & 4,00 & 0 & 0,00 & \\
\hline Sarjana & 10 & 40,00 & 5 & 33,33 & \\
\hline Total & 25 & 100 & 15 & 100 & \\
\hline \multicolumn{6}{|l|}{$\begin{array}{l}\text { Jumlah Anggota } \\
\text { Keluarga (Orang) }\end{array}$} \\
\hline$<2$ & 6 & 24,00 & 4 & 26,67 & \multirow{4}{*}{0,036} \\
\hline $2-3$ & 10 & 40,00 & 6 & 40,00 & \\
\hline $3-5$ & 6 & 24,00 & 3 & 20,00 & \\
\hline$>5$ & 3 & 12,00 & 2 & 13,33 & \\
\hline Total & 25 & 100 & 15 & 100 & \\
\hline \multicolumn{6}{|l|}{$\begin{array}{c}\text { Tingkat } \\
\text { Pendapatan (Rp.) }\end{array}$} \\
\hline$<500.000$ & 5 & 20 & 4 & 26,67 & \multirow{5}{*}{0,024} \\
\hline $600.000-1.000 .000$ & 6 & 24 & 4 & 26,67 & \\
\hline $1.100 .000-2.000 .000$ & 5 & 20 & 3 & 20,00 & \\
\hline $2.100 .000-3.000 .000$ & 7 & 28 & 3 & 20,00 & \\
\hline$>3.000 .000$ & 2 & 8 & 1 & 6,67 & \\
\hline Total & 25 & 100 & 15 & 100 & \\
\hline
\end{tabular}

Sumber: Analisis Data Primer, 2020 
Timisela, N. R., Lawalata, M., Jozias, V., Polnaya, F. J., Titaley, S.: Permintaan Konsumen ...

Tabel 3. Hasil analisis regresi permintaan konsumen terhadap sayuran organik

\begin{tabular}{ccccc}
\hline Uraian & Koefisien Regresi & Standar Error & t-hitung & Probabilitas \\
\hline (Constant) & 0,660 & 0,247 & 2,668 & 0,011 \\
X1 & $-0,002$ & 0,000 & $-2,085$ & 0,043 \\
X2 & 0,001 & 0,000 & 2,165 & 0,035 \\
X3 & 0,020 & 0,035 & 0,569 & 0,573 \\
X4 & 0,206 & 0,034 & 6,125 & 0,000 \\
X5 & 0,023 & 0,030 & 2,476 & 0,004 \\
X6 & 0,056 & 0,048 & 3,037 & 0,003 \\
\hline
\end{tabular}

Sumber: Analisis Data Primer, 2020

Keterangan: X1 = Harga sayuran organik; X2 = Harga sayuran non organik; X3 = Pendapatan; X4 = Jumlah anggota keluarga; X5 = Selera; X6 = Frekuensi pembelian.

terkait dengan perilaku orang dan melalui pendidikan akan mendewasan orang untuk berperilaku baik untuk memilih dan membuat keputusan terbaik dan tepat untuk melakukan pembelian sayuran organik. Pendidikan ikut menentukan proporsi untuk menggunakan pendapatan dengan baik dan benar untuk konsumsi dalam keluarga. Keluarga akan menentukan kuantitas, keanekaragaman bahan pangan organik yang dikonsumsi dan kualitas bahan pangan organik tersebut.

Jumlah anggota keluarga berhubungan dengan keputusan konsumen melakukan pembelian sayuran organik. Nilai $p$-value 0,036 $<0,25$ artinya terdapat hubungan erat antara jumlah anggota keluarga dengan keputusan pembelian sayuran organik. Jumlah anggota keluarga semakin besar maka keputusan pembelian sayuran organik akan lebih besar. Karena konsumen mempunyai keinginan besar untuk memberikan makanan sehat bagi anggota keluarganya. Hal ini didukung oleh pendapat Raharjda dan Manurung (2001) bahwa keputusan pembelian tergantung jumlah anggota keluarga, semakin banyak anggota keluarga maka jumlah pembelian bahan pangan akan semakin banyak.

Kualitas maupun kuantitas barang yang akan dibeli tergantung besaran pendapatan konsumen. Jika konsumen berpendapatan tinggi akan cenderung membeli barang yang berkualitas dengan jumlah yang sesuai. Sebaliknya jika konsumen berpendapatan rendah maka akan membeli barang sesuai kondisi keuangan dan kualitas barang tidak menjadi perhatian utama. Menurut Sarwono (2005) bahwa pendapatan tinggi memungkinkan seseorang melakukan kegiatan atau kebutuhan lainnya lebih baik karena memiliki kondisi keuangan yang cukup. Pendapatan meningkat akan terjadi perubahan dalam menata komposisi makanan yang akan dikonsumsi dan lebih berkualitas. Hasil analisis terlihat bahwa $p$-value 0,024 $<0,25$ artinya bahwa terhadap hubungan erat antara tingkat pendapatan dengan keputusan pembelian sayuran organik oleh konsumen. Tingkat Pendapatan berkaitan dengan pola konsumsi keluarga. Jika pendapatan naik maka pola konsumsi juga naik dan sebaliknya jika pendapatan rendah maka pola konsumsi juga rendah. Harga sayuran organik cenderung lebih mahal dibandingkan harga sayuran non organik. Konsumen akan menentukan pilihan terbaik dengan kondisi keuangannya untuk mendapatkan produk tersebut. Sekalipun harga mahal tetapi karena sayuran organik ramah lingkungan dan baik untuk kesehatan maka kosumen tetap akan mengambil keputusan membeli sayuran organik dengan kondisi pendapatan yang sesuai. Hal ini didukung oleh penelitian Silitonga dan Salman (2014), bahwa pembelian terhadap suatu produk akan dilakukan apabila konsumen telah melakukan pertimbangan tertentu. Konsumen melakukan pembelian sayuran organik karena manfaat sayuran organik yang begitu banyak seperti sayuran organik baik bagi kesehatan. Disamping itu juga sayuran organik lebih enak karena sayuran organik dibudidaya secara organik sehingga rasanya lebih enak dibanding dengan sayuran non-organik.

\section{Permintaan Sayuran Organik}

Hubungan antara jumlah barang yang diminta dengan harga barang merupakan permintaan. Permintaan suatu barang akan berubah jika cita rasa atau pendapatan atau harga barang lain berubah (Sukirno, 2011). Permintaan barang dipengaruhi oleh berbagai faktor seperti pendapatan, selera, harga barang sendiri, jumlah penduduk, harga barang lain, perkiraan 


\section{Konsumen ...}

harga, distribusi pendapatan dan usaha-usaha produsen (Rahardja dan Manurun, 2008).

Hasil penelitian menunjukkan bahwa terdapat enam faktor yang memengaruhi permintaan konsumen terhadap sayuran organik di pasar Pulau Saparua antara lain harga sayuran organik, harga sayuran non organik, pendapatan, jumlah anggota keluarga, selera dan frekuensi pembelian. Faktor-faktor tersebut dianalisis menggunakan regresi linier berganda, hasil pengujian ditampilkan pada Tabel 3.

Koefisien determinasi (Adjusted $R$ Square) 0,630 atau $63,0 \%$. Artinya 63,0 persen permintaan sayuran organik dapat dijelaskan oleh keenam factor sisanya 37,0\% permintaan sayuran organik dipengaruhi faktor lain di luar model.

Hasil uji $\mathrm{F}$ menunjukan $\mathrm{F}_{\text {hitung }}$ 17,630 > $F_{\text {tabel }} 5$ persen sebesar 2,64. Artinya harga sayuran organik, harga sayuran non organik, jumlah anggota keluarga, pendapatan, selera dan frekuensi pembelian secara simultan berpengaruh nyata terhadap permintaan sayuran organik.

Tabel 3 menunjukkan bahwa variabel harga sayuran non organik, jumlah anggota keluarga, pendapatan, selera dan frekuensi pembelian berpengaruh positif terhadap permintaan sayuran organik. Hubungan positif menunjukkan bahwa variabel harga sayuran non organik, pendapatan dan anggota keluarga memiliki perubahan yang searah dengan permintaan sayuran organik. Variabel harga sayuran organik berhubungan negatif terhadap permintaan sayuran organik. Hubungan negatif menunjukkan arah yang berlawanan yakni jika harga sayuran organik naik maka permintaan akan menurun.

\section{Harga Sayuran Organik}

Tedjakusuma et al. (2001) menyatakan bahwa faktor harga berpengaruh terhadap keputusan seseorang untuk melakukan pembelian. Terdapat orang yang mempunyai kepedulian tinggi, bersedia membayar mahal untuk pengadaan produk pertanian organik karena dianggap sangat bermanfaat untuk kesehatan dan lingkungan. Hasil analisis menunjukkan bahwa koefisien regresi untuk harga sayuran organik bernilai negatif terhadap permintaan sayuran organik sebesar 0,002. Apabila harga sayuran organik meningkat, maka permintaan konsumen terhadap sayuran organik menurun. Nilai $t_{\text {hitung }}(2,085)>t_{\text {tabel }}(1,69)$. Variabel harga sayuran organik bepengaruh signifikan, hal ini menunjukkan bahwa permintaan sayuran organik cukup baik. Sayuran organik di pasar Pulau Saparua selalu tersedia pada hasil pasar Rabu dan Sabtu, sehingga mencukupi kebutuhan permintaan konsumen.

\section{Harga Sayuran Non Organik}

Hasil analisis harga sayuran non organik menunjukkan koefisien regresi bernilai positif terhadap permintaan konsumen yaitu 0,001. Apabila harga sayuran non organik naik maka permintaan sayuran organik naik. Hasil uji t menunjukkan $t_{\text {hitung }}(2,165)>t_{\text {tabel }}(1,69)$. Artinya harga sayuran non organik memiliki pengaruh yang signifikan terhadap permintaan sayuran organik bagi konsumen yang melakukan pembelian sayuran organik.

Jika harga sayuran non organik meningkat maka konsumen tidak bersedia membeli dan akan memilih untuk membeli sayuran organik dengan harga yang dapat dijangkau (Timisela et al, 2017). Harga sayuran non organik berpengaruh positif terhadap permintaan sayuran organik. Harga sayuran non organik meningkat tetapi konsumen memiliki kesadaran akan pentingnya mengkonsumsi bahan pangan organik maka mereka lebih cenderung membelanjakan uangnya untuk pangan oganik. Harga sayuran organik tidak berbeda dengan harga sayuran non organik. Bahkan di pasar terlihat bahwa harga sayuran non organik semakin menurun karena konsumen lebih banyak membeli sayuran organik. Pedagang di pasar sekalipun menjual sayuran non organik dengan harga rendah, tetapi konsumen akan membeli sayuran organik karena harga sayuran organik masih dapat dijangkau. Hasil ini sejalan dengan penelitian Khorniawati (2014), bahwa kesadaran konsumen lebih baik karena banyak mengetahui kandungan zat kimia pada produk pertanian non organik sehingga konsumen memilih untuk terus mengkonsumsi produk organik yang aman bagi kesehatan tubuh.

\section{Pendapatan}

Konsumen dengan pendapatan tinggi sering membeli makanan organik untuk mencerminkan kesadaran dan status mereka (Deliana, 2012). Ketika pendapatan konsumen 
meningkat, maka minat dan keinginan untuk mengkonsumsi produk sayuran organik meningkat (Maswadi, 2012). Hasil analisis variabel pendapatan terlihat bahwa pendapatan berpengaruh positif terhadap permintaan konsumen yaitu 0,020. Artinya apabila pendapatan konsumen naik, maka permintaan sayuran organik naik.

Nilai $t_{\text {hitung }}(0,569)<t_{\text {tabel }}(1,69)$, artinya pendapatan tidak berpengaruh signifikan terhadap permintaan sayuran organik. Berapapun pendapatan konsumen baik rendah maupun tinggi, konsumen tetap membelanjakan uangnya untuk sayuran organik. Jika pendapatan tinggi maka konsumen akan membeli sayuran dalam jumlah besar atau sebaliknya. Hal ini tidak dilakukan oleh konsumen karena sifat produk pertanian terutama sayuran tidak bisa disimpan lama, cepat rusak dan membusuk. Pasar di Pulau Saparua berlangsung 2 kali dalam seminggu sehingga petani harus memasok sayuran organik ke pasar secara kontinu sesuai hari pasar. Pedagang di pasar membeli sayuran dari petani untuk dijual kepada konsumen. Hal ini berlangsung terus menerus setiap 2 kali seminggu sehingga persediaan sayuran organik tetap ada di pasar. Konsumen ke pasar untuk membeli sayuran organik dan kebutuhan lain untuk dikonsumsi 1-2 hari kedepan. Hal ini penting bagi konsumen karena sangat tergantung waktu pasar di Pulau Saparua.

\section{Jumlah Anggota Keluarga}

Jumlah anggota keluarga berpengaruh terhadap keputusan konsumen untuk mengadakan pembelian. Semakin besar jumlah anggota keluarga berarti tingkat pembelanjaan akan semakin tinggi. Keputusan konsumen untuk membeli tergatung pada besarnya jumlah anggota keluarga Raharjo dan Manurung (2001).

Hasil analisis pada Tabel 2 menunjukkan koefisien regresi jumlah anggota keluarga berpengaruh positif dengan permintaan sayuran organik yaitu 0,206. Apabila jumlah anggota keluarga bertambah maka permintaan bertambah. Nilai $t_{\text {hitung }}(6,125)>t_{\text {tabel }}(1,69)$. Artinya jumlah anggota keluarga memiliki pengaruh yang signifikan terhadap permintaan.

Jumlah anggota keluarga sebagai penentu banyaknya sayuran organik yang dibeli konsumen untuk dikonsumsi. Jika jumlah anggota keluarga besar, konsumen membeli sayuran organik dalam jumlah besar dan sebaliknya jika jumlah anggota keluarga sedikit, konsumen membeli sayuran organik dalam jumlah relatif sedikit. Penelitian Dasipah (2010) mendukung pernyataan di atas bahwa dalam melakukan pembelian produk keputusan keluarga sangat berpengaruh dikarenakan keinginan setiap anggota keluarga berbedabeda.

\section{Selera}

Selera adalah kebutuhan pelanggan terhadap suatu produk yang sesuai dengan keinginan. Selera konsumen berbeda-beda menurut kemauan dan kemampuan pembelajaan. Selera dapat berubah dari waktu ke waktu. Selera konsumen untuk barang tertentu akan berpengaruh pada naiknya jumlah permintaan barang itu. Sebaliknya jika selera menurun maka permintaan terhadap barang tersebut akan berkurang. Jika selera tinggi maka keputusan untuk membeli barang juga akan tinggi.

Hasil analisis regresi menghasilkan nilai koefisien untuk selera 0,023 bernilai positif artinya jika selera konsumen bertambah maka permintaan konsumen terhadap sayuran organik akan bertambah 0,023 satuan. Uji thitung $(2,476)>$ t-tabel 1,69 artinya selera berpengaruh signifikan terhadap permintaan sayuran organik. Keinginan konsumen untuk membeli sayuran organik semakin meningkat karena selera konsumen di Pulau Saparua saat ini lebih tinggi untuk mengkosumsi sayuran organik. Konsumen memilih untuk mengkonsumsi sayuran organik karena selera dalam keluarga juga sangat tinggi sehingga permintaan semakin menaik.

Menurut Kotler (2005) selera merupakan faktor yang berpengaruh terhadap keputusan keonsumen untuk melakukan pembelian. Hal ini sejalan dengan penelitian di atas. Selera mencakup beberapa aspek seperti kesan kosumen dan melakukan pembelian, daya tahan produk, nilai guna produk, bentuk produk, desain dan tampilan produk. Tampilan produk sayuran organik sangat menarik sekalipun ada lubang-lubang tetapi karena nilai guna sayuran organik tinggi dan konsumen berkesan maka dengan sendiri akan muncul selera untuk membeli sayuran organik. 
Timisela, N. R., Lawalata, M., Jozias, V., Polnaya, F. J., Titaley, S.: Permintaan Konsumen ...

\section{Frekuensi Pembelian}

Pedagang maupun petani melakukan penjualan sayuran organik di pasar Pulau Saparua terjadi dua kali dalam seminggu berdasarkan hari pasar yaitu hari Rabu dan hari Sabtu. Konsumen biasanya membeli sayuran organik di pasar. Frekuensi pembelian terbagi atas tiga bagian yaitu sering membeli (55\%), kadangkadang membeli (25\%) dan jarang membeli (20\%). Hasil analisis regresi menunjukkan bahwa frekuensi pembelian juga memengaruhi permintaan kosumen terhadap sayuran organik. Nilai koefisien regresi waktu beli 0,056 artinya jika hari pasar ditambahkan konsumen akan tetap menambah jumlah pembelian sayuran organik. Nilai t-hitung 3,037 > t-tabel 1,69, frekuensi pembelian berpengaruh signifikan terhadap permintaan kosumen untuk sayuran organik dikarenakan kedua waktu pasar di Pulau Saparua, terjadi permintaan terhadap sayuran organik cukup baik dan hal ini menjadi rangsangan bagi konsumen bahwa mereka akan tetap mencari sayuran organik ke petani penghasil sayuran organik supaya pola konsumsi terus berkelanjutan.

\section{KESIMPULAN}

Hasil analisis hubungan karakteristik dengan keputusan konsumen membeli sayuran organik terlihat bahwa pendidikan, jumlah anggota keluargadan pendapatan berhubungan erat keputusan konsumen untuk membeli sayuran organik. Hasil analisis regresi menunjukkan bahwa keenam faktor secara simultan berpengaruh nyata terhadap permintaan konsumen untuk sayuran organic di pasar Pulau Saparua. Adapun faktor yang berpengaruh secara individu atau parsial adalah harga sayuran organik, harga sayuran non organik, jumlah anggota keluarga, selera dan frekuensi pembelian. Nilai Adjusted $\mathrm{R}$ Square menujunjukkan 63,0 persen permintaan sayuran organik dapat dijelaskan oleh keenam variabel yang di dalam model sedangkan sisanya 37,0 persen permintaan sayuran organik dipengaruhi faktor lain di luar model. Sayuran organik diminati oleh konsumen sehingga keputusan untuk melakukan pembelian sayuran oganik cukup baik. Faktor harga sayuran organik, harga sayuran non organik, jumlah anggota keluarga, selera dan frekuensi pembelian berpengaruh terhadap permintaan sayuran organik. Kajian kelima faktor tersebut menunjukkan bahwa mengkonsumsi sayuran organik penting untuk tetap menjaga kesehatan tubuh dan memperbaiki kualitas hidup konsumen.

\section{DAFTAR PUSTAKA}

Briz, T., \& Ward, R. W. (2009). Consumer awareness of organic products in Spain: An application of multinominal logit models. Food Policy, 34(3), 295-304.

Dasipah, Budiyono. (2010). Analisis perilaku konsumen dalam pembelian produk sayuran di pasar modern Kota Bekasi. Jurnal Administrasi Bisnis (JAB), 1(2), 24-37.

Deliana, Y. (2012). Consumer preferences on organic and anorganic vegetable in Bandung, West Java, Indonesia. Research Journal of Recent, 1, 212-218.

Gracia, A., \& de Magistris, T. (2008). The demand for organic foods in the South of Italy: A discrete choice model. Food Policy, 33(5), 386-396.

Hubeis, M., Najib, M., Widyastuti, H., \& Wijaya, N. H. (2013). Strategi Produksi Pangan Organik Bernilai Tambah Tinggi Yang Berbasis Petani. Jurnal Ilmu Pertanian Indonesia, 18(3), 194-199.

Isdiayanti. (2007). Analisis usahatani sayuran organik di perusahaan Matahari Farm [Skripsi]. Fakultas Pertanian, Institut Pertanian Bogor, Bogor.

Jozias, V., Timisela, N. R. T., \& Lawalata, M. (2020). Analisis segmentasi pasar sayuran organik di Pulau Saparua Kabupaten Maluku Tengah. SEPA: Jurnal Sosial Ekonomi Pertanian Dan Agribisnis, 17(1), 72-82.

Khorniawati, M. (2014). Produk pertanian organik di Indonesia: Tinjauan atas preferensi konsumen Indonesia terhadap produk pertanian organik lokal. Journal of Chemical Information and Modeling, 8(2), 171-182. 
Timisela, N. R., Lawalata, M., Jozias, V., Polnaya, F. J., Titaley, S.: Permintaan Konsumen ...

Kotler, P. (2005). Manajemen Pemasaran. Terjemahan Molan Benyam in Marketing Management. Jilid 1 (Edisi Kesebelas). Jakarta: Indeks.

Kriyantono, R. (2006). Teknis Praktis Riset Komunikasi. Jakarta : Kencana

Lockie, S., Lyons, K., Lawrence, G., \& Mummery, K. (2002). Eating "green": motivations behind organic food consumption in Australia. Sociologia Ruralis, 42(1), 23-40.

Maswadi. (2012). Kajian faktor kepribadian perilaku konsumen terhadap pembelian sayur organik di supermarket Kota Pontianak. Jurnal EKSOS, 8, 1-8.

Mayrowani, H. 2012. Pengembangan pertanian organik di Indonesia. Forum Penelitian Agro Ekonomi, 30(2), 91-108.

Rahman, S., Ekalestari, A., \& Ruhumuddin. (2015). IbM Kelompok Tani sayuran organik di Kota Makassar. Majalah Aplikasi Ipteks NGAYAH, 6(1), 9-19.

Rahardja, P., \& Manurung, M. 2008. Pengantar Ilmu Ekonomi (Mikroekonomi \& Makroekonomi) (Edisi Ketiga). Jakarta: Fakultas Ekonomi Universitas Indonesia.

Silitonga, J., \& Salman. (2014). Analysis of consumer demand for organic vegetable in modern market Pekanbaru City. Jurnal Dinamika Pertanian, 113(1), 7986.

Soler, F., Jose, G., \& Mercedes, S. (2002). Consumer's acceptability of organic food in Spain: Result from an Experimental Auction Market, Brithish. Food Journal, 8(104): 670-687.

Sugiyono. (2018). Statistik Nonparametris Untuk Penelitian. Bandung : Alfabeta.

Sukirno,S. (2011). Mikro Ekonomi Teori Pengantar (Edisi Ketiga). Jakarta: Rajawali Pers.

Tedjakusuma, Ritawati, Hartini, S., \& Muryani. (2001). Analisis faktor-faktor yang memengaruhi perilaku konsumen dalam pembelian air minum mineral di Kotamadya Surabaya. Jurnal Penelitian Dinamika Sosial, 2(3), 48-58.

Timisela, N. R. (2017). The demand of organic vegetables at Frismart Modern Market in Ambon City. Journal of Economics and Sustainable Development, 8(18), 132139.

Timisela, N. R., Leatemia, E. D., \& Polnaya, F. (2018). Supply chain sayuran organik di Kota Ambon. Prosiding Semnas PPM, 1(1): 637-645.

Tsakiridou, E., Konstantinos, M., \& Tzimitra, K. I. (2006). The infuence of consumer characteristics and attitudes on the demand for organic olive oil. Journal International Food Agribusiness Market, 18(3-4): 23-31.

Winangun, Y. W. W. 2005. Membangun Karakter Petani Organik Sukses dalam Era Globalisasi. Yogyakarta : Kanisius. 